\title{
In vitro effects of Coriandrum sativum, Tagetes minuta, Alpinia zerumbet and Lantana camara essential oils on Haemonchus contortus
}

\author{
Efeitos in vitro dos óleos essenciais de Coriandrum sativum, Tagetes minuta, Alpinia zerumbet \\ e Lantana camara sobre Haemonchus contortus
}

Iara Tersia Freitas Macedo ${ }^{1}$; Lorena Mayana Beserra de Oliveira ${ }^{1}$; Ana Lourdes Fernandes Camurça-Vasconcelos ${ }^{1}$; Wesley Lyeverton Correia Ribeiro' ${ }^{1}$ Jessica Maria Leite dos Santos ${ }^{1}$; Selene Maia de Morais²;

Haroldo Cesar Beserra de Paula³; Claudia Maria Leal Bevilaqua ${ }^{1 *}$

\begin{abstract}
${ }^{1}$ Laboratório de Doenças Parasitárias, Programa de Pós-graduação em Ciências Veterinárias, Universidade Estadual do Ceará - UECE, Fortaleza, CE, Brasil

${ }^{2}$ Laboratório de Produtos Naturais, Universidade Estadual do Ceará - UECE, Fortaleza, CE, Brasil

${ }^{3}$ Laboratório de Química de Biopolímeros, Universidade Federal do Ceará - UFC, Fortaleza, CE, Brasil
\end{abstract}

Received February 28, 2013

Accepted June 24, 2013

\begin{abstract}
Phytotherapy can be an alternative for the control of gastrointestinal parasites of small ruminants. This study evaluated the efficacy of Alpinia zerumbet, Coriandrum sativum, Tagetes minuta and Lantana camara essential oils by two in vitro assays on Haemonchus contortus, an egg hatch test (EHT) and larval development test (LDT). No effect was observed for L. camara in the EHT. A. zerumbet, C. sativum and T. minuta essential oils exhibited a dose-dependent effect in the EHT, inhibiting $81.2,99$ and $98.1 \%$ of $H$. contortus larvae hatching, respectively, at a concentration of $2.5 \mathrm{mg} \mathrm{mL}^{-1}$. The effective concentration to inhibit 50\% (EC50) of egg hatching was $0.94,0.63$ and $0.53 \mathrm{mg} \mathrm{mL}^{-1}$ for A. zerumbet, C. sativum and T. minuta essential oils, respectively. In LDT, L. camara, A. zerumbet, C. sativum and T. minuta at concentration of $10 \mathrm{mg} \mathrm{mL}^{-1}$ inhibited 54.9, 94.2, 97.8 and $99.5 \%$ of $H$. contortus larval development, presenting EC50 values of 6.32, 3.88, 2.89 and $1.67 \mathrm{mg} \mathrm{mL}^{-1}$, respectively. Based on the promising results presented in this in vitro model, it may be possible use of these essential oils to control gastrointestinal nematodes. However, their anthelmintic activity should be confirmed in vivo.
\end{abstract}

Keywords: Phytotherapy, anthelmintic, gastrointestinal nematodes.

\section{Resumo}

Fitoterapia pode ser uma alternativa para o controle de parasitas gastrintestinais de pequenos ruminantes. Este estudo avaliou a eficácia dos óleos essenciais de Alpinia zerumbet, Coriandrum sativum, Tagetes minuta e Lantana camara sobre Haemonchus contortus através de dois testes in vitro, teste de eclosão dos ovos (TEO) e teste de desenvolvimento larval (TDL). Nenhum efeito foi observado para L. camara no TEO. Os óleos essenciais de A. zerumbet, C. sativum e T. minuta exibiram um efeito dose dependente no TEO inibindo a eclosão das larvas de H. contortus em 81,2, 99 e $98,1 \%$, respectivamente, na concentração de $2,5 \mathrm{mg} \mathrm{mL}^{-1}$. A concentraçáo efetiva para inibir $50 \%$ (CE50) da eclosão dos ovos foi de 0,94, 0,63 e 0,53 mg mL $\mathrm{m}^{-1}$ para os óleos essenciais de $A$. zerumbet, C. sativum e T. minuta, respectivamente. No TDL, $10 \mathrm{mg} \mathrm{mL}^{-1}$ de L. camara, A. zerumbet, C. sativum e T. minuta inibiram em 54,9, 94,2, 97,8 e 99,5\% do desenvolvimento larvar, apresentando valores de CE50 de 6,32, 3,88, 2,89 e 1,67 $\mathrm{mg} \mathrm{mL}^{-1}$, respectivamente. Com base nos resultados promissores apresentados neste modelo in vitro, pode ser possível a utilização destes óleos essenciais para controlar os nematoides gastrintestinais. No entanto, a sua atividade anti-helmíntica deve ser confirmada in vivo.

Palavras-chave: Fitoterapia, anti-helmínticos, nematoides gastrintestinais.

\footnotetext{
${ }^{*}$ Corresponding author: Claudia Maria Leal Bevilaqua

Programa de Pós-graduação em Ciências Veterinárias, Faculdade de

Veterinária - FAVET, Universidade Estadual do Ceará - UECE, Av. Dede

Brasil, 1700, Campus do Itaperi, CEP 60714-903, Fortaleza, CE, Brasil

e-mail: claudiamlb@yahoo.com.br
} 


\section{Introduction}

Parasitic nematodes are a major threat to livestock production worldwide leading to huge economic losses (ADEMOLA; ELLOF, 2010), because of the support treatments and increased manpower that the infected animals require and because of the high mortality rate within flocks, especially in small ruminants (DIEHL et al., 2004). Anthelmintics have been used to minimize the losses caused by helminth infections. However, the efficacy of anthelmintics is increasingly endangered by development of resistance in nematode populations (MILLER et al., 2012). Control by anthelmintics has presented problems, such as the development of resistance in nematodes, the poor availability and high cost of commercial products, especially to low income farmers in developing countries, and increasing concern over the risk of environmental contamination because the presence of drug residues in animal products when pure compounds are administered (WALLER, 2006). These concerns have led to the search for and evaluation of alternative control methods (ATHANASIADOU et al., 2001). One promising alternative investigated for the control of gastrointestinal parasites has been the use of phytotherapics (MAPHOSA et al., 2010). Efforts are being made to evaluate several medicinal plants for their anthelmintic potential in different parts of the world. Haemonchus contortus, a highly pathogenic and one of the most prevalent nematode parasite, has been used by researchers to evaluate the anthelmintic effects of plants in small ruminants (EGUALE et al., 2011).

Among the criteria used to select plant species are their availability and the existence of studies researching their biological activity on nematodes. Of the plant species that have been documented as having medicinal effects against helminths, Lantana camara, Tagetes minuta (ALBUQUERQUE et al., 2007), Alpinia zerumbet (ALMEIDA, 1993) and Coriandrum sativum (HUSSAIN et al., 2008) are commonly cited.

L. camara, belonging to the Verbenaceae family, exhibits antimicrobial activity (DEENA; THOPPIL, 2000), efficacy against termite workers (VERMA; VERMA, 2006) and has a nematostatic effect on the phytonematode Meloidogyne incognita (DIAS et al., 2000). T. minuta, from the Asteraceae family, has fungitoxic effects (ROZWALKA et al., 2008), activity against Anopheles stephensi larvae (HADJIAKHOONDI et al., 2005), antibacterial activity (SOUZA et al., 2000) and effect on $H$. contortus egg and larvae (MACEDO et al., 2012). A. zerumbet, from the Zingiberaceae family, exhibits antioxidant (ELZAAWELY et al., 2007), antibacterial and antifungal activities (VICTÓRIO et al., 2009). C. sativum, belonging to the Umbelliferae family, has antifungal activity (FURLETTI et al., 2011), nematicidal activity against the phytonematode Bursaphelenchus xylophilus (KIM et al., 2008), and anthelmintic activity on gastrointestinal nematodes (EGUALE et al., 2007).

The objective of this study was to evaluate the effects of essential oils of L. camara, A. zerumbet, C. sativum and T. minuta on the egg hatching and larval development of $H$. contortus.

\section{Materials and Methods}

\section{Plants and essential oils}

L. camara, A. zerumbet and T. minuta were collected in Fortaleza, State of Ceará, Brazil, in campus of Universidade Estadual do Ceará in January of 2010. These plants were authenticated in the Herbarium Prisco Bezerra of the Universidade Federal do Ceará and voucher specimens were deposited under the numbers 46017, 49659, and 49676, respectively. The seeds of $C$. sativum were purchased commercially from the local market of Fortaleza.

To prepare essential oils, fresh aerial parts of $2.0 \mathrm{~kg}$ of L. camara, $2.7 \mathrm{~kg}$ of $A$. zerumbet, and $0.8 \mathrm{~kg}$ of $T$. minuta and $1.0 \mathrm{~kg}$ of seeds of $C$. sativum were separately subjected to hydrodistillation for 3 hours in a Clevenger-type apparatus. The calculation of yield was done and the oils were stored at $4^{\circ} \mathrm{C}$ until use.

\section{Egg hatch test}

The egg hatch test (EHT) was performed based on the methodology described by Coles et al. (1992). Sheep experimentally infected with $H$. contortus were used as a source of fresh eggs. $H$. contortus eggs were recovered according to Hubert and Kerboeuf (1992) and Oliveira et al. (2009). Briefly, $10 \mathrm{~g}$ of feces, collected directly from the rectum, were mixed with distilled water and filtered through 590, 149, 101 and $30 \mu \mathrm{m}$ mesh sieves. To increase the aqueous solubility, the oils were diluted in 3\% Tween 80 . An egg suspension $(250 \mu \mathrm{L})$ containing approximately 100 fresh eggs was incubated with $250 \mu \mathrm{L}$ essential oils at concentrations from 0.15 to $10 \mathrm{mg} \mathrm{mL}^{-1}$ for $48 \mathrm{~h}$ at $25^{\circ} \mathrm{C}$. Drops of Lugol were added. The eggs and first larval stage (L1) were counted under a microscope. This test had two controls: a negative control containing the diluent (3\% Tween 80 ) and a positive control, $0.025 \mathrm{mg} \mathrm{mL}^{-1}$ of thiabendazole. Three repetitions with five replicates for each essential oil concentration and for each control were performed.

\section{Larval development test}

A larval development test (LDT) was performed according Camurça-Vasconcelos et al. (2007). For this, $H$. contortus eggs were incubated for $24 \mathrm{~h}$ at $28^{\circ} \mathrm{C}$ to obtain the $\mathrm{L} 1$. Next, $1 \mathrm{~mL}$ of larval suspension containing approximately $250 \mathrm{~L} 1$ and $1 \mathrm{~mL}$ of essential oils at concentrations of 0.62 to $20 \mathrm{mg} \mathrm{mL}^{-1}$ were incubated with $2 \mathrm{~g}$ feces from a nematode-free sheep for 6 days at room temperature. Then, the third-stage larvae (L3) were recovered according to Roberts and O'Sullivan (1950) and counted under a microscope. This test had two controls, a negative with 3\% Tween 80 and a positive with $0.008 \mathrm{mg} \mathrm{mL}^{-1}$ ivermectin. Three repetitions with five replicates for each oil concentration and for each control were conducted.

\section{Chemical analysis}

The chemical composition of the essential oils used in this study was determined by gas chromatography (GC) and mass spectrometry 
(MS). The oil was analyzed on a Hewlett-Packard 5971 instrument using the following experimental conditions: DB-1-coated fused silica capillary column $(30 \mathrm{~m} \times 0.25 \mathrm{~mm})$ - carrier gas - helio; injector temperature $-220{ }^{\circ} \mathrm{C}$; detector temperature $-200{ }^{\circ} \mathrm{C}$; column temperature program $-35-180{ }^{\circ} \mathrm{C}$ at $48{ }^{\circ} \mathrm{C} / \mathrm{min}$, then $180-250^{\circ} \mathrm{C}$ at $10^{\circ} \mathrm{C} / \mathrm{min}$. For MS, the electron impact was $70 \mathrm{eV}$.

Compounds were identified by their GC retention time, expressed by Kovat's index, which was calculated by the Van den Dool and Kratz equation using a hydrocarbon homologous series and by comparison of test compound mass spectra with those present in the National Institute for Standard Technology computer data bank (NIST; 62,235 compounds) and published spectra (ADAMS, 2001).

\section{Statistical analysis}

The effectiveness of each treatment on the EHT was determined based on the percentage of larvae, using the following formula: number of larvae/(number larvae + number eggs) $\times 100$.

The inhibition percentage of the LDT was calculated based on the percentage reduction in the $\mathrm{L} 3$ recovered compared to the negative control group (number of L3 in the control group - number of L3 in the treated group)/number of L3 in control group $\times 100$.

The results of the in vitro tests are expressed as the percentage of egg hatching or larval development inhibition. Data were analyzed using ANOVA and compared by the Tukey test $(P<0.05)$ using the GraphPad Prism program 5.0. The effective concentrations that inhibited 50\% (EC50) of egg hatching and larval development were determined by the probit method using SPSS 8.0 for Windows.

\section{Results}

The yields of the essential oil were $0.05 \%$ to L. camara, $0.14 \%$ to $T$. minuta, $0.24 \%$ from $C$. sativum and $0.38 \%$ to A. zerumbet.

The mean percentages of the effectiveness of the essential oils obtained in the EHT are presented in Table 1. L. camara was not effective against egg hatching at the concentrations tested. However, the oils of $A$. zerumbet, T. minuta and $C$. sativum present at concentrations $\geq 1.25 \mathrm{mg} \mathrm{mL}^{-1}$ egg hatch inhibition superior to negative control $(P<0.05)$.

Table 2 shows the mean efficacy of essential oils by the LDT. The effective concentration of $L$. camara was $20 \mathrm{mg} \mathrm{mL}^{-1}$, did not differ from positive control $(P>0.05)$. However, at a concentration of $10 \mathrm{mg} \mathrm{mL}^{-1}$, the $A$. zerumbet and $C$. sativum oils had similar efficacy to the positive control $(P>0.05)$. Moreover, the effectiveness of $5 \mathrm{mg} \mathrm{mL}^{-1} T$. minuta was not significantly different from the positive control $(P>0.05)$.

The EC50 values for the EHT and LDT are shown in Table 3. The oils tested on the larvae and eggs of $H$. contortus showed a dose-dependent effect.

The constituents of the essential oils are shown in Table 4. The major constituents of $A$. zerumbet oil were 1,8-cineole (24.69\%), p-cimene (22.56\%) and 4-terpineol (17.43\%); L. camara contained caryophyllene oxide (50.26\%); T. minuta contained piperitone (86.27\%) and C. sativum contained beta linalool (73.21\%).

Table 1. Mean efficacy \pm standard error of Lantana camara, Alpinia zerumbet, Coriandrum sativum and Tagetes minuta essential oils on Haemonchus contortus egg hatching.

\begin{tabular}{ccccc}
\hline Concentrations $\left(\mathbf{m g} \cdot \mathbf{m L}^{-1}\right)$ & L. camara & A. zerumbet & C. sativum & T. minuta \\
\hline 0.15 & - & - & $14.8 \pm 1.9 \mathrm{Aa}$ & $18.1 \pm 1.0 \mathrm{Aa}$ \\
0.31 & - & $7.5 \pm 0.8 \mathrm{Aa}$ & $28.6 \pm 1.9 \mathrm{Bb}$ & $28.0 \pm 2.0 \mathrm{Bb}$ \\
0.62 & $18.1 \pm 2.2 \mathrm{Aa}$ & $34.8 \pm 1.9 \mathrm{Bb}$ & $36.8 \pm 1.8 \mathrm{Cb}$ & $49.6 \pm 2.4 \mathrm{Cc}$ \\
1.25 & $20.8 \pm 1.8 \mathrm{ABa}$ & $65.1 \pm 2.5 \mathrm{Cb}$ & $64.1 \pm 1.5 \mathrm{Db}$ & $74.1 \pm 1.9 \mathrm{Dc}$ \\
2.5 & $26.1 \pm 1.7 \mathrm{BCa}$ & $81.2 \pm 2.4 \mathrm{Db}$ & $99.0 \pm 0.2 \mathrm{Ec}$ & $98.1 \pm 0.5 \mathrm{Ec}$ \\
5 & $26.8 \pm 1.7 \mathrm{BCa}$ & $100.0 \pm 0.0 \mathrm{~Eb}$ & - & $-100.0 \pm 0.0 \mathrm{~Eb}$ \\
10 & $30.5 \pm 1.2 \mathrm{C}$ & - & - & - \\
Tween $80(3 \%)$ & $12.8 \pm 0.8 \mathrm{Aa}$ & $14.3 \pm 1.1 \mathrm{Aa}$ & $11.7 \pm 1.1 \mathrm{Aa}$ & $11.2 \pm 0.8 \mathrm{Fa}$ \\
Thiabendazole $\left(0.025 \mathrm{mg} \cdot \mathrm{mL}^{-1}\right)$ & $96.2 \pm 0.6 \mathrm{Da}$ & $96.2 \pm 0.6 \mathrm{Ea}$ & $96.2 \pm 0.6 \mathrm{Ea}$ & $96.2 \pm 0.6 \mathrm{Ea}$ \\
\hline
\end{tabular}

Capital letters compare mean in the columns and small letters compare mean in the lines. Different letters indicate significantly different values $(P<0.05)$.

Table 2. Mean percentage efficacy \pm standard error of Alpinia zerumbet, Coriandrum sativum, Tagetes minuta and Lantana camara essential oils on Haemonchus contortus larval development.

\begin{tabular}{ccccc}
\hline Concentrations $\left(\mathbf{m g} . \mathbf{m L}^{-1}\right)$ & L. camara & A. zerumbet & C. sativum & T. minuta \\
\hline 0.62 & - & - & - & $12.1 \pm 4.2 \mathrm{~A}$ \\
1.25 & $10.5 \pm 3.7 \mathrm{Aa}$ & $4.0 \pm 1.4 \mathrm{Aa}$ & $10.1 \pm 3.1 \mathrm{Aa}$ & $44.5 \pm 2.6 \mathrm{Bb}$ \\
2.5 & $21.3 \pm 6.5 \mathrm{ABa}$ & $31.7 \pm 4.5 \mathrm{Bab}$ & $42.6 \pm 2.8 \mathrm{Bbc}$ & $55.1 \pm 3.6 \mathrm{Bc}$ \\
5 & $31.9 \pm 4.4 \mathrm{Ba}$ & $55.2 \pm 3.4 \mathrm{Cb}$ & $77.8 \pm 2.3 \mathrm{Cc}$ & $92.9 \pm 2.3 \mathrm{Cc}$ \\
10 & $54.9 \pm 3.4 \mathrm{Ca}$ & $94.2 \pm 1.4 \mathrm{Db}$ & $97.8 \pm 1.1 \mathrm{Db}$ & $99.5 \pm 0.2 \mathrm{Cb}$ \\
20 & $97.7 \pm 0.5 \mathrm{Da}$ & $100 \pm 0.0 \mathrm{Da}$ & $99.5 \pm 0.3 \mathrm{Da}$ & - \\
Tween $80(3 \%)$ & $7.2 \pm 3.4 \mathrm{Aa}$ & $8.2 \pm 2.1 \mathrm{Aa}$ & $6.6 \pm 2.0 \mathrm{Aa}$ & $4.8 \pm 1.6 \mathrm{Aa}$ \\
Ivermectin $\left(0.008 \mathrm{mg} \cdot \mathrm{mL}^{-1}\right)$ & $99.9 \pm 0.0 \mathrm{Da}$ & $99.9 \pm 0.0 \mathrm{Da}$ & $99.9 \pm 0.0 \mathrm{Da}$ & $99.9 \pm 0.0 \mathrm{Ca}$ \\
\hline
\end{tabular}

Capital letters compare mean in the columns and small letters compare mean in the lines. Different letters indicate significantly different values $(P<0.05)$. 
Table 3. Effective concentration (mg.mL ${ }^{-1}$ ) to inhibit 50\% (EC50) of egg hatch test (EHT) and larval development test (LDT) of Alpinia zerumbet, Coriandrum sativum, Tagetes minuta and Lantana camara essential oils on Haemonchus contortus.

\begin{tabular}{lcccc}
\hline \multicolumn{1}{c}{ Essentials oils } & \multicolumn{3}{c}{ EHT } & \multicolumn{2}{c}{ LDT } \\
\cline { 2 - 5 } & EC50 & Confidence Limits & EC50 & Confidence Limits \\
\hline L. camara & - & - & 6.32 & $2.93-19.25$ \\
A. zerumbet & 0.94 & $0.67-1.28$ & 3.88 & $2.94-5.09$ \\
C. sativum & 0.63 & $0.27-1.84$ & 2.89 & $2.60-3.20$ \\
T. minuta & 0.53 & $0.31-0.85$ & 1.67 & $1.02-2.53$ \\
\hline
\end{tabular}

Table 4. Percentage relative composition of Alpinia zerumbet, Lantana camara, Tagetes minuta and Coriandrum sativum essential oils.

\begin{tabular}{|c|c|c|c|c|c|}
\hline Constituents & KI & A. zerumbet & L. camara & T. minuta & C. sativum \\
\hline Alpha Tujene & 931 & 0.91 & - & - & - \\
\hline Alpha Pinene & 932 & - & - & - & 4.2 \\
\hline Camphene & 944 & - & - & - & 0.56 \\
\hline Beta Pinene & 972 & - & - & - & 0.42 \\
\hline Sabinene & 976 & 4.46 & - & - & - \\
\hline Beta Myrcene & 995 & - & - & - & 0.65 \\
\hline Alpha Feladrene & 1005 & 2.51 & - & - & - \\
\hline 4-Carene & 1011 & 7.33 & - & - & - \\
\hline o-Cimene & 1020 & - & - & - & 0.94 \\
\hline Silvestrene & 1027 & 4.55 & - & - & - \\
\hline Limonene & 1031 & - & - & 13.73 & 1.86 \\
\hline 1,8-Cineole & 1033 & 24.69 & - & - & - \\
\hline Gamma-Terpinene & 1062 & 11.56 & - & - & - \\
\hline Terpinene & 1064 & - & - & - & 3.10 \\
\hline Tertpinolene & 1088 & 1.84 & - & - & 0.50 \\
\hline P-Cimene & 1089 & 22.56 & - & - & - \\
\hline Beta linalool & 1091 & - & - & - & 73.21 \\
\hline Camphor & 1139 & - & - & - & 4.25 \\
\hline Borneol & 1162 & - & - & - & 0.98 \\
\hline 4-terpineol & 1177 & 17.43 & - & - & - \\
\hline Piperitone & 1252 & - & - & 86.27 & - \\
\hline Copaene & 1376 & - & 10.58 & - & - \\
\hline Beta-elemene & 1391 & - & 2.74 & - & - \\
\hline Beta-Caryophyllene & 1418 & - & 7.51 & - & - \\
\hline Beta-gurjunene & 1432 & - & 1.88 & - & - \\
\hline Alpha murolene & 1499 & - & 1.31 & - & - \\
\hline Nerolidol & 1564 & - & 13.1 & - & - \\
\hline Espalenol & 1576 & - & 3.18 & - & - \\
\hline Caryophyllene Oxide & 1581 & - & 50.26 & - & - \\
\hline Total identified & & 97.84 & 90.56 & 100 & 90.67 \\
\hline
\end{tabular}

KI - Kovats index; (-) means not detected. The values in bold are to highlight the chemical constituents found in higher percentage in the essential oil.

\section{Discussion}

This study verified the presence of biologically active compounds that had ovicidal effect on $H$. contortus in the essential oils of A. zerumbet, C. sativum and T. minuta. The oils inhibited egg hatching at a low concentration compared to other plants that have been studied previously. Ocimum gratissimum essential oil inhibited $100 \%$ of egg hatching at a concentration of $50 \mathrm{mg} \mathrm{mL}^{-1}$ (PESSOA et al., 2002). The maximum effectiveness of the essential oil of Eucalyptus globulus on eggs was $99.3 \%$ at a concentration of $21.75 \mathrm{mg} \mathrm{mL}^{-1}$ (MACEDO et al., 2009). In other study, the decoction of $L$. camara also did not act on eggs and decoctions of A. zerumbet and T. minuta exhibited inferior efficacy, inhibiting 97.5 and $96.8 \%$ of egg hatching at a concentration 5 and $2.5 \mathrm{mg} \mathrm{mL}^{-1}$, respectively (MACEDO et al., 2012). However, the crude aqueous and hydro-alcoholic extracts of the seeds of $C$. sativum completely inhibited the hatching of egg at a concentration of less than $0.5 \mathrm{mg} \mathrm{mL}^{-1}$. Phytochemical screening of these extracts revealed the presence of secondary metabolites such as alkaloids and flavonoids, which are considered to be the chemical components that are responsible for the wide therapeutic activities of several medicinal plants (EGUALE et al., 2007). Variation in activity 
between the extract types and essential oil might be due to differences in the proportion of the active components responsible for the tested anthelmintic activity.

The most potent oil tested in LDT was T. minuta, which exhibited superior efficacy to other oils tested previously with an EC50 of $1.67 \mathrm{mg} \mathrm{mL}^{-1}$. The essential oil of Eucalyptus citriodora had an EC50 of $2.71 \mathrm{mg} \mathrm{mL}^{-1}$ (MACEDO et al., 2011). The EC50 of Lippia sidoides essential oil was $2.97 \mathrm{mg} \mathrm{mL}^{-1}$ (CAMURÇAVASCONCELOS et al., 2007). However, T. minuta essential oil was similar to Eucalyptus staigeriana essential oil, which had an EC50 of $1.70 \mathrm{mg} \mathrm{mL}^{-1}$ (MACEDO et al., 2010).

Transcuticular diffusion is a common method of entry into in helminth parasites for non-nutrient and non-electrolyte substances (EGUALE et al., 2007). It has also been shown that this route, rather than oral ingestion, predominates for the uptake of major broad-spectrum anthelmintics. It is easier for lipophilic anthelmintics to cross the external surface of helminths than it is for hydrophilic compounds (GEARY et al., 1999). The low density of plant oils and their rapid diffusion across cell membranes can enhance the targeting of the active components of essential oils into endoparasites (ANTHONY et al., 2005).

Essential oils are composed of a mixture of chemical substances whose interaction can result in compounds that can interfere with nematode metabolism, inhibiting or disorganizing vital functions from the initial stages of development onward, and can furthermore interfere with drive mechanisms due to possible destructuring of the nervous system (OKA et al., 2000). Essential oils can interact with the cytoplasmic membrane and may disrupt the structure of polysaccharides, lipids and phospholipids, promoting membrane depolarization and the consequent alteration of its permeability (BAKKALI et al., 2008), as reported for fungi exposed to essential oils (HAMMER et al., 2004).

Chemical analysis identified components with high concentrations in essential oils that may be responsible for their anthelmintic activity. The main component of $A$. zerumbet was 1,8-cineol, which has previously been shown to have antibacterial activity (CHA et al., 2007), antifungal activity (TERZI et al., 2007) and activity against the nematode Anisakis simplex (NAVARRO et al., 2008). The main component of L. camara was caryophyllene oxide, an antifungal agent (YANG et al., 1999) that has analgesic and anti-inflammatory activity (CHAVAN et al., 2010). The main component of $C$. sativum was linalool, which has antibacterial activity (FISHER et al., 2007) and insecticidal activity against Tribolium castaneum (STAMOPOULOS et al., 2007), Oryzaephilus surinamensis, Musca domestica and Blattella germanica (LEE et al., 2003), and nematicidal activity against juveniles of the root-knot nematode, Meloidogyne incognita (LEELA et al., 1992). The major constituent of T. minuta, piperitone was an antioxidant (DAR et al., 2011), which has insecticidal activity against larvae of Spodoptera littoralis and fungicidal activity (ABDELGALEIL et al., 2008).

The plants evaluated in the current study had already been reported as anthelmintic agents. Therefore, the current finding is the first step to justify their use in folk medicine. Further investigation of isolated fractions at different dose levels should be pursued. In addition, tests with animals can be performed with $A$. zerumbet, C. sativum and T. minuta essential oils to evaluate the toxicity and to confirm their anthelmintic activity in target species.

\section{Acknowledgements}

This work received financial support from the Conselho Nacional de Desenvolvimento Científico e Tecnológico (CNPq) and Fundação Cearense de Apoio ao Desenvolvimento Científico e Tecnológico. Dr. Bevilaqua has a grant from CNPq.

\section{References}

Abdelgaleil SAM, Abbassy MA, Belal ASH, Rasoul MAAA. Bioactivity of two major constituents isolated from the essential oil of Artemisia judaica L. Bioresour Technol 2008; 99(13): 5947-5950. http://dx.doi. org/10.1016/j.biortech.2007.10.043

Adams RP. Identification of essential oil components by gas chromatography/ quadrupole mass spectroscopy. Illinois: Allured; 2001. 804 p.

Ademola IO, Eloff JN. In vitro anthelmintic activity of Combretum molle (R. Br. ex G. Don) (Combretaceae) against Haemonchus contortus ova and larvae. Vet Parasitol 2010; 169(1-2): 198-203. http://dx.doi. org/10.1016/j.vetpar.2009.12.036

Albuquerque UP, Medeiros PM, Almeida AL, Monteiro JM, Lins EMF No, Melo JG, et al. Medicinal plants of the caatinga (semi-arid) vegetation of NE Brazil: A quantitative approach. $J$ Ethnopharmacol 2007; 114(3): 325-354. http://dx.doi.org/10.1016/j. jep.2007.08.017

Almeida ER. Plantas medicinais brasileiras: conhecimentos populares e científicos. Hemus: São Paulo; 1993. 341 p.

Anthony JP, Fyfe L, Smith H. Plant active components - a resource for antiparasitic agents? Trends Parasitol 2005; 21(10): 462-468. http:// dx.doi.org/10.1016/j.pt.2005.08.004

Athanasiadou S, Kyriazakis I, Jackson F, Coop RL. Direct anthelmintic effects of condensed tannins towards different gastrointestinal nematodes of sheep: in vitro and in vivo studies. Vet Parasitol 2001; 99(3): 205-219. http://dx.doi.org/10.1016/S0304-4017(01)00467-8

Bakkali F, Averbeck S, Averbeck D, Idaomar M. Biological effects of essential oils - A review. Food Chem Toxicol 2008; 46(2): 446-475. http:// dx.doi.org/ 10.1016/j.fct.2007.09.106

Camurça-Vasconcelos ALF, Bevilaqua CML, Morais SM, Maciel MV, Costa CTC, Macedo ITF, et al. Anthelmintic activity of Croton zehntneri and Lippia sidoides essential oils. Vet Parasitol 2007; 148(3-4): 288-294. http://dx.doi.org/10.1016/j.vetpar.2007.06.012

Cha JD, Jung EK, Kil BS, Lee KY. Chemical composition and antibacterial activity of essential oil from Artemisia feddei.J Microbiol Biotechnol 2007; 17(12): 2061-2065.

Chavan MJ, Wakte PS, Shinde DB. Analgesic and anti-inflammatory activity of Caryophyllene oxide from Annona squamosa L. bark. Phytomedicine 2010; 17(2): 149-151. http://dx.doi.org/10.1016/j. phymed.2009.05.016

Coles GC, Bauer C, Borgsteede FHM, Geerts S, Klei TR, Taylor MA, et al. World Association for the Advancement of Veterinary Parasitology (W.A.A.V.P.) methods for the detection of anthelmintic resistance in nematodes of veterinary importance. Vet Parasitol 1992; 44(1-2): 35-44. http://dx.doi.org/10.1016/0304-4017(92)90141-U

Dar MY, Shah WA, Rather MA, Qurishi Y, Hamid A, Qurishi MA. Chemical composition, in vitro cytotoxic and antioxidant activities of the essential oil and major constituents of Cymbopogon jawarancusa 
(Kashmir). Food Chem 2011; 129(4): 1606-1611. http://dx.doi. org/10.1016/j.foodchem.2011.06.016

Deena MJ, Thoppil JE. Antimicrobial activity of the essential oil of Lantana camara. Fitoterapia 2000; 71(4): 453-455. http://dx.doi. org/10.1016/S0367-326X(00)00140-4

Dias CR, Schwan AV, Ezequiel DP, Sarmento MC, Ferraz S. Efeito de extratos aquosos de plantas medicinais na sobrevivência de Junenis de Meloidogyne incognita. Nematol Bras 2000; 24(2): 203-210.

Diehl MS, Atindehou KK, Tere H, Betschart B. Prospect for anthelminthic plants in the Ivory Coast using ethnobotanical criteria. $J$ Ethnopharmacol 2004; 95(2-3): 277-284. http://dx.doi.org/10.1016/j. jep.2004.07.012

EgualeT, Tadesse D, Giday M. In vitro anthelmintic activity of crude extracts of five medicinal plants against egg-hatching and larval development of Haemonchus contortus. J Ethnopharmacol 2011; 137(1): 108-113. http:// dx.doi.org/10.1016/j.jep.2011.04.063

Eguale T, Tilahun G, Debella A, Feleke A, Makonnen E. In vitro and in vivo anthelmintic activity of crude extracts of Coriandrum sativum against Haemonchus contortus. J Ethnopharmacol 2007; 110(3): 428-433. http:// dx.doi.org/10.1016/j.jep.2006.10.003

Elzaawely AA, Xuan TD, Tawata S. Essential oils, kava pyrones and phenolic compounds from leaves and rhizomes of Alpinia zerumbet (Pers.) B.L. Burtt. \& R.M. Sm. and their antioxidant activity. Food Chem 2007; 103(2): 486-494. http://dx.doi.org/10.1016/j. foodchem.2006.08.025

Fisher K, Rowe C, Phillips CA. The survival of three strains of Arcobacter butzleri in the presence of lemon, orange and bergamot essential oils and their components in vitro and on food. Lett Appl Microbiol 2007; 44: 495499. http://dx.doi.org/ 10.1111/j.1472-765X.2006.02106.x

Furletti VF, Teixeira IP, Obando-Pereda G, Mardegan RC, Sartoratto A, Figueira GM, et al. Action of Coriandrum sativum L. essential oil upon oral Candida albicans biofilm formation. Evid-Based Complement Alternat Med 2011; 2011: 1-9. http://dx.doi.org/10.1155/2011/985832

Geary TG, Sangster NC, Thompson DP. Frontiers in anthelmintic pharmacology. Vet Parasitol 1999; 84(3-4): 275-295. http://dx.doi. org/10.1016/S0304-4017(99)00042-4

Hadjiakhoondi A, Vatandoost H, Khanavi M, Abaee RM, Karami M. Biochemical investigation of different extracts and larvicidal activity of Tagetes minuta L. on Anopheles stephensi larvae. Iran J Pharm Sci 2005; 1(2): 81-84.

Hammer KA, Carson CF, Riley TV. Antifungal effects of Melaleuca alternifolia (tea tree) oil and its components on Candida albicans, Candida glabrata and Saccharomyces cerevisiae. I Antimicrob Chemother 2004; 53(6): 1081-1085.

Hubert J, Kerboeuf D. A microlarval development assay for the detection of anthelmintic resistance in sheep nematodes. Vet Rec 1992; 130(20): 442-446. http://dx.doi.org/10.1136/vr.130.20.442

Hussain A, Khan MN, Iqbal Z, Sajid MS. An account of the botanical anthelmintics used in traditional veterinary practices in Sahiwal district of Punjab, Pakistan. J Ethnopharmacol 2008; 119(1): 185-190. http:// dx.doi.org/10.1016/j.jep.2008.06.034

Kim J, Seo SM, Lee SG, Shin SC, Park IK. Nematicidal activity of plant essential oils and components from coriander (Coriandrum sativum), oriental sweetgum (Liquidambar orientalis), and valerian (Valeriana wallichii) essential oils against pine wood nematode (Bursaphelenchus xylophilus). J Agric Food Chem 2008; 56(16): 7316-7320. http://dx.doi. org/10.1021/jf800780f

Lee S, Peterson CJ, Coats JR. Fumigation toxicity of monoterpenoids to several stored product insects. J Stored Prod Res 2003; 39: 77-85. http:// dx.doi.org/10.1016/S0022-474X(02)00020-6

Leela NK, Khan RM, Reddy PP, Nidiry ESJ. Nematicidal activity of essential oil of Pelargonium graveolens against the root-knot nematode Meloidogyne incognita. Nematol Medit 1992; 20(1): 57-58.

Macedo ITF, Bevilaqua CML, Oliveira LMB, Camurça-Vasconcelos ALF, Morais SM, Machado LKA, et al. In vitro activity of Lantana camara, Alpinia zerumbet, Mentha villosa and Tagetes minuta decoctions on Haemonchus contortus eggs and larvae. Vet Parasitol 2012; 190(3-4): 504509. http://dx.doi.org/10.1016/j.vetpar.2012.07.001

Macedo ITF, Bevilaqua CML, Oliveira LMB, Camurça-Vasconcelos ALF, Vieira LS, Amóra SSA. Avaliação do óleo essencial de Eucalyptus citriodora sobre nematóides gastrintestinais de caprinos. Rev Bras Parasitol Vet 2011; 20(3): 223-227. http://dx.doi.org/10.1590/S198429612011000300009

Macedo ITF, Bevilaqua CML, Oliveira LMB, Camurça-Vasconcelos ALF, Vieira LS, Oliveira FR, et al. Atividade ovicida e larvicida in vitro do óleo essencial de Eucalyptus globulus sobre Haemonchus contortus. Rev Bras Parasitol Vet 2009; 18(3): 62-66. http://dx.doi.org/10.4322/ rbpv.01803011

Macedo ITF, Bevilaqua CML, Oliveira LMB, Camurça-Vasconcelos ALF, Vieira LS, Oliveira FR, et al. Anthelmintic effect of Eucalyptus staigeriana essential oil against goat gastrointestinal nematodes. Vet Parasitol 2010; 173(1-2): 93-98. http://dx.doi.org/10.1016/j. vetpar.2010.06.004

Maphosa V, Masika PJ, Bizimenyera ES, Eloff JN. In vitro anthelminthic activity of crude aqueous extracts of Aloe ferox, Leonotis leonurus and Elephantorrhiza elephantina against Haemonchus contortus. Trop Anim Health Prod 2010; 42(2): 301-307. http://dx.doi.org/10.1007/s11250009-9421-9

Miller CM, Waghorn TS, Leathwick DM, Candy PM, Oliver AMB, Watson TG. The production cost of anthelmintic resistance in lambs. Vet Parasitol 2012; 186(3-4): 376-381. http://dx.doi.org/10.1016/j. vetpar.2011.11.063

Navarro MC, Noguera MA, Romero MC, Montilla MP, Selgas JMG, Valero A. Anisakis simplex s.l.: Larvicidal activity of various monoterpenic derivatives of natural origin against L3 larvae in vitro and in vivo. Exp Parasitol 2008; 120(4): 295-299. http://dx.doi.org/10.1016/j. exppara.2008.07.014

Oka Y, Nacar S, Putievsky E, Ravid U, Zohara Y, Spiegel Y. Nematicidal activity of essential oils and their components against the root-knot nematode. Phytopathology 2000; 90(7): 710- 715.

Oliveira LMB, Bevilaqua CML, Costa CTC, Macedo ITF, Barros RS, Rodrigues ACM, et al. Anthelmintic Activity of Cocos nucifera L. Against Sheep Gastrointestinal Nematodes. Vet Parasitol 2009; 159(1): 55-59. http://dx.doi.org/10.1016/j.vetpar.2008.10.018

Pessoa LM, Morais SM, Bevilaqua CM, Luciano JHS. Anthelmintic activity of essential oil of Ocimun gratissimum Linn. and eugenol against Haemonchus contortus. Vet Parasitol 2002; 109(1-2): 59-63. http://dx.doi. org/10.1016/S0304-4017(02)00253-4

Roberts FHS, O'Sullivan PJ. Methods for egg counts and larval cultures for strongyles infecting the gastrointestinal tract of cattle. Aust J Agric Res 1950; 1: 99-102. http://dx.doi.org/10.1071/AR9500099 
Rozwalka LC, Lima MLRZC, Mio LLM, Nakashima T. Extratos, decoctos e óleos essenciais de plantas medicinais e aromáticas na inibição de Glomerella cingulata e Colletotrichum gloeosporioides de frutos de goiaba. Cienc Rural 2008; 38(2): 301-307. http://dx.doi.org/10.1590/ S0103-84782008000200001

Souza CAS, Avancini CAM, Wiest JM. Atividade antimicrobiana de Tagetes minuta L. - Compositae (Chinchilho) frente a bactérias Grampositivas e Gram-negativas. BrazJ Vet Res Anim Sci 2000; 37(6): 429-433. http://dx.doi.org/10.1590/S1413-95962000000600001

Stamopoulos DC, Damos P, Karagianidou G. Bioactivity of five monoterpenoid vapours to Tribolium confusum (du Val) (Coleoptera : Tenebrionidae). J Stored Prod Res 2007; 43(4): 571-577. http://dx.doi. org/10.1016/j.jspr.2007.03.007

Terzi V, Morcia C, Faccioli P, Vale G, Tacconi G, Malnati M. In vitro antifungal activity of the tea tree (Melaleuca alternifolia) essential oil and its major components against plant pathogens. Lett Appl
Microbiol 2007; 44(6): 613-618. http://dx.doi.org/10.1111/j.1472765X.2007.02128.x

Verma RK, Verma SK. Phytochemical and termiticidal study of Lantana camara var. aculeata leaves. Fitoterapia 2006; 77(6): 466-468. http:// dx.doi.org/10.1016/j.fitote.2006.05.014

Victório CP, Alviano DS, Alviano CS, Lage CLS. Chemical composition of the fractions of leaf oil of Alpinia zerumbet (Pers.) B. L. Burtt \& R. M. Sm. and antimicrobial activity. Rev Bras Farmacogn 2009; 19(3): 697701. http://dx.doi.org/10.1590/S0102-695X2009000500008

Waller PJ. From discovery to development: Current industry perspectives for the development of novel methods of helminth control in livestock. Vet Parasitol 2006; 139(1-3): 1-14. http://dx.doi.org/10.1016/j. vetpar.2006.02.036

Yang D, Michel L, Chaumont JP, Millet-Clerc J. Use of caryophyllene oxide as an antifungal agent in an in vitro experimental model of onychomycosis. Mycopathologia 1999; 148(2): 79-82. 